\section{Knowledge that traveled between Italy and Spain during the Franco regime: the construction of radioactivity counters}

\author{
Conhecimento itinerante \\ entre a Itália e a Espanha \\ durante o regime de Franco: \\ a construção dos medidores \\ de radioatividade
}

ROMERO DE PABLOS, Ana. Knowledge that traveled between Italy and Spain during the Franco regime: the construction of radioactivity counters. História, Ciências, Saúde - Manguinhos, Rio de Janeiro, v.26, n.1, jan.-mar. 2019, p.265-279.

\section{Abstract}

In this paper I propose a reflection on instruments and political power. The objective is to analyze how the knowledge, experiences, and practices that circulated and traveled via radioactivity counters between Italy and Spain constructed and influenced both nuclear energy and political power during the Franco regime. I show people, materials, instruments, and knowledge that traveled, which permits us to think about the Spanish scientists and their role in the circulation of scientific materials and knowledge and as vectors of diplomatic and political relations.

Keywords: radioactivity counters; nuclear policy; early Francoism; Spain; Italy.

\section{Resumo}

Este artigo propõe uma reflexão sobre os instrumentos e o poder político. O objetivo é analisar como o conhecimento, as experiências, e práticas que circularam e viajaram entre a Itália e a Espanha, por meio dos contadores de radioatividade, construíram e influenciaram tanto a energia nuclear e o poder político durante o regime de Franco. O trabalho revela pessoas, materiais, instrumentos e conhecimentos itinerantes que nos permite pensar nos cientistas espanhóis e no seu papel na circulação de material e conhecimento científicos, ao mesmo tempo que atuaram como vetores das relações diplomáticas e políticas da época.

Palavras-chave: medidores de radioatividade; política nuclear; primórdios do Franquismo; Espanha; Itália. 
tarting from the last decades of the twentieth century, work done on discoveries and scientific theories in the history of science have been enriched by adding an interest in the material culture of science and technology and its practices. The publication of the volume of Osiris entitled "Instruments," edited by Albert Van Helden and Thomas L. Hankins (1994), is indicative of an increased interest in this area within the academic community of historians of science (Warner, 1990; Charadevian, 1993). This interest, as can be seen nearly two decades later in the Isis issue "Focus: the History of Scientific Instruments," edited by Liba Taub (2011), has reconfigured scientific instruments outside of laboratories and museums, making them more complex and giving them new meanings (Rheinberger, 2001; Bourguet, Licoppe, Sibum, 2003; Bennett, 2003, 2011; Schaffer, 2005, 2011; Arnold, Söderqvist, 2011; Valverde, 2016).

In this paper, I will show radioactivity counters and the work developed with them as being participants in a wide network of political, scientific, and military institutions, Spanish as well as foreign, which determined Spanish nuclear policy during the Franco dictatorship. In the latter years of the 1940s and during the 1950s, the priorities for the still emerging nuclear policy of Franco's government were to train personnel, set out a research agenda, and find models to organize and equip laboratories. Hidden behind these priorities was an interest by the dictatorship authorities in constructing a network of political and military alliances that would place Spain on the international relations map. Radioactivity counters, I suggest, participated in this process. These instruments were used as mediators; they established protocols for how to act inside and outside the laboratories, strengthened exchange networks, and also participated in the making of political, economic, and social decisions (Schaffer, 2005).

The recent historiography on nuclear energy development in Spain has shown that it was a process mediated by scientific and technical matters, as well as by political and economic factors. Works that have explained nuclear development as being a result of political and institutional aspects (Romero de Pablos, Sánchez Ron, 2001; Presas, 2008; Ordóñez, Sánchez Ron, 1996) have been supplemented by others that point out the dissonance between the supposedly modernizing intention of policies favoring the entrance of this technology and the reactionary context in which they arose (Herran, Roqué, 2012). The close relationship between the medical use of radioactive isotopes and the development of intentional propaganda campaigns in favor of atomic energy also played a part in the acceptance and circulation of the new technology (Herran, 2009; Santesmases, 2006, 2009). More recent studies have analyzed the industrial and economic consequences of nuclear development for Spain (De la Torre, Rubio-Varas, 2015a, 2015b; Romero de Pablos, 2012), radiological protection, and its relationship with the industry (Menéndez-Navarro, Sánchez Vázquez, 2013), as well as the role the media played in constructing the discourse that circulated about this technology (Romero de Pablos, 2018; Menéndez-Navarro, 2007; Ramírez Martínez, 2011; Ordóñez, Ramírez, 2008; Nieto-Galán, 2012, 2013). It is a historiography that as a whole reflects on knowledge, experiences, and practices that circulated, and on artefacts, policies, and desires that traveled and helped with learning. In this case study, I suggest a dialogue between political and cultural uses, which are often forgotten in the history of science, with scientists and technicians. 
Following Rheinberger's (1997, p.4) notion of "epistemic things," I propose thinking about radioactivity counters and the other materials that traveled as being objects laden with knowledge and experiences that circulated and were reproduced, adapted, and appropriated (Pancaldi, 2003; Edgerton, 2007). In this process of circulation and appropriation, political, social, economic, and commercial factors, along with theoretical and technological factors, also had importance (Rentetzi, 2008; Arnold, Söderqvist, 2011). Travel conditioned the "matter and meaning," in the words of Lorraine Daston (2004, p.10), of the radioactivity counters, while at the same time legitimizing the political power of the Franco dictatorship during the 1950s in Spain.

In this paper I propose a reflection on instruments, circulation, and political power to analyze how the knowledge, experiences, and practices that circulated and traveled between Italy and Spain via radioactivity counters constructed and influenced both nuclear energy and political power during the Franco regime. I also show the people, materials, instruments, and knowledge that traveled and crossed borders. The concepts of knowledge in transit, circulation, reception, and adaptation are present in this paper to widen the meanings of "international science" in dialogue with recent essays on globalization and transnational sciences (Secord, 2004; Turchetti, Herran, Boudia, 2012; Suárez-Díaz, Mateos, Barahona, 2015; Santesmases, 2018, chapter 8).

\section{The Spanish scenario}

After Second World War, Franco's support of Hitler and Mussolini left Spain outside international forums such as the United Nations, which vetoed Spain in June 1945 and recommended to all its member states that their representatives abandon Spanish soil. However, far from disappearing, Spanish connections with Italy were reinforced. At the end of the 1940s, the Spanish dictatorship used the research spaces organized around nuclear physics in Italy to construct their political and diplomatic relations. In November 1950, the United Nations lifted the veto on Spain, although its definitive integration into the bloc only happened in 1953, after the signing of the Madrid Agreements (Pactos de Madrid) between the United States and Spain. As of 1950, Spain began to participate in different international organizations: in 1951, it entered the Food and Agriculture Organization of the United Nations; in 1953, the United Nations Educational, Scientific and Cultural Organization; in 1956, the International Labour Organization; and in 1958, Spain entered the International Monetary Fund.

In this context, the government of the dictatorship turned to the internationalization of science and its scientists, and took advantage of the opportunities offered them from various international political and scientific institutions. In this article, I explore what happened with the Centro di Informazioni, Studi ed Esperienze research center (CISE) and the National Institute for Nuclear Physics at the University in Rome.

The interest that the discovery of uranium ore deposits in the Sierra Albarrana mountains in Córdoba, southern Spain, had aroused at the end of the 1930s, reinforced by the optimistic numbers circulated by Berilio and Radio Español S.A., the company that privately exploited it (Carbonell, 1945), helped place Spain, for a while, among the countries with 
large uranium reserves. This enthusiasm drove the creation of a commission in 1946 to map and study possible uranium deposits for their later exploitation at the Spanish Mining and Geological Institute (Instituto Geológico y Minero) and was the origin of the agreement the Franco government established with the Italians in 1948. The interests and wishes of this commission and the problems they faced, such as ignorance about techniques and a lack of technology, were gathered in the volume titled Uranio: cursos de conferencias (1946), edited by the institute.

After the Second World War, the Spanish government took advantage of the strategic and diplomatic significance uranium acquired. On September 27, 1949, the New York Herald Tribune, in its Paris edition, published an article entitled "Discovery of Rich Uranium Deposits in the Spanish Pyrenees" (27 Sep., 1949). This report showed the interest the United States government had in knowing, controlling, and monitoring deposits of this mineral. The Spanish uranium constituted, according to this journalist, "a coveted triumph" that would lead the powers in the Atlantic Treaty to modify their attitude towards the Franco regime. The discoveries in the Spanish mines became agents of this change. As Adamson, Camprubí, and Turchetti (2014, p.23) have written, uranium became an object of intelligence missions, a product of knowledge hybridization, and a techno-political asset.

Added to the euphoria around the possibilities offered by uranium was the Spanish government's need to design a research agenda to find models to organize and equip laboratories. The National Institute for Nuclear Physics at the University in Rome and CISE, in Milan, were the inspirational model for the institutionalization of nuclear development in Spain. Both institutions had opened their doors to Spanish researchers in 1948 after the agreed-upon payment of $214 \mathrm{~kg}$ of uranium, which allowed Franco's regime to reproduce research and instruments developed there (Agreement Between..., 1948). In 1948, Franco created the Atomic Research Council (Junta de Investigaciones Atómicas, JIA), an organization dependent on the Ministry of the President, hidden until 1951 behind a commercial business called Estudios y Patentes de Aleaciones Especiales (Studies and Patents for Special Alloys). It was precisely the possible exploitation of the uranium mines in southern Spain and the idea to use this material as hard currency to obtain training and technical information from abroad that were the basis for some of the arguments motivating this commercial company. In 1951, the Nuclear Energy Council (Junta de Energía Nuclear, JEN) was created, which meant the end of the process of institutionalizing Franco's nuclear policy and, in part, an end to the secrecy that had ruled this policy up to then (Romero de Pablos, Sánchez Ron, 2001, p.13-49) .

Spain and Italy negotiated a cooperative space where they could make up for their deficiencies, which appeared to be of experience and training in the case of the Spaniards, and of uranium ore for the Italians. And, as already mentioned, radioactivity counters had their agency in this process.

One of the issues on the nuclear policy and research agenda was to study the techniques for constructing radioactivity counters. Techniques and devices, as well as ways of organizing and institutionalizing nuclear development, traveled along with these counters (Secord, 2004). As we will see further on, the experiences, knowledge, and practices that were in transit with these instruments reinforced the rhetoric of nationalization, which 
was present in the autocratic discourses of the dictatorship: the international contacts helped strengthen the national-catholic regime. Up to midway through the 1950s, discourse on nuclear energy had been directed at strengthening the autarchic politics of the Franco regime. The attendance of a large group of Spanish politicians, researchers, and entrepreneurs at the first Atoms for Peace conference, held in Geneva in 1955, introduced a change into the discourse of the Franco authorities, who, from then on, held up nuclear energy as a banner for opportunities that would offer an opening into foreign lands (Romero de Pablos, 2018).

\section{Italy/Spain}

The collaboration between Italy and Spain started with the agreed-upon payment in 1948 of $214 \mathrm{~kg}$ of uranium, which allowed the Spanish researchers to familiarize themselves with the organization and equipment at the Italian laboratories, their work practices, and the state of their research. This agreement also opened up spaces for the exchange of results and collaboration on industrial projects. In exchange for uranium from Spanish mines, CISE also committed to providing technical help for mineral prospecting work on Spanish territory (Agreement Between..., 1948).

The first result of the agreement signed between JIA and CISE appeared in October 1948 with the arrival in Madrid of a group of Italian prospecting experts. Along with Giuseppe Bolla, director of CISE, were a geologist, a petrographer - an expert in rock description and a physicist specializing in instrumentation, who had designed the radiation detector devices they brought with them to Spain. Joining them were two Spanish mining engineers, José María Ríos and Demetrio Santana, from the Mining and Geological Institute. The Spaniards and Italians worked together for a month at the deposits in the Sierra Albarrana. After prospecting in the three places considered to be the richest in the area, the Italian group estimated that there could be around ten tons of uranium oxide: quite different from the 850 tons that Antonio Carbonell had estimated. The reports written by each group agreed on the need to do additional studies to more rigorously establish the extent of the uranium and the deposits (Otero Navascues, 11 Jul. 1949, p.19-21).

The practices and prospecting experiences that began at Sierra Albarrana continued later in other parts of Spain (Cáceres, Salamanca, Coruña, and Zamora). While discovering possible new spaces for mineral extraction, the work done by the Spanish and Italian researchers also brought to light technical problems that from then on were an object of study for the Spanish researchers: the prospecting jobs, increasingly more numerous, required not only a larger number of radioactivity counters, but also ones that were more manageable, portable, and lighter, like the counters the Italians had brought with them.

As we will see in the third part of this article, this was the beginning of research done by a group of Spanish physicists, who, concerned with finding answers to these problems, began to think about and experiment with the construction of circuits, amplifiers, and pulse counters for Geiger-Müller tubes at the University of Madrid. 


\section{Spain/ltaly}

The agreement between JIA and CISE included a visit to Italy by Spanish physicists to train in nuclear physics. María Aránzazu Vigón, Ramón Ortiz Fornaguera, and Carlos Sánchez de Río were the three selected. Although I am going to relate the experiences and knowledge acquired by all three researchers who formed part of this trip, I will focus on the woman in the group, as she was responsible for studying the construction and workings of the radioactivity counters. Reinstating this researcher and her work, along with the instruments she handled, which are essential to the history of atomic energy and the practices of measuring ionizing radiation, expands the reflection on how gender issues affected the circulation of radiation counters (Rentetzi, 2004, 2008; Rheinberger, 2001). The records of her work in the institution's reports and publications show a researcher with technical and experimental authority equal to that of many of her peers. But she remained obscured by, as well as confused with, her male colleagues. This was due to the format of academic citations, which only included the initials of first names, the large work groups that characterize the practice of physics, and the collective authorship of the results. But above all, she remained silenced by the male gender of scientific and political authority in regard to nuclear energy.

The family environment in which María Aránzazu Vigón grew up and was educated influenced her professional life. She was one of eight siblings, all of whom, including her three sisters, studied at university. She was the daughter of General Vigón, who was a minister in the first cabinet of the Franco dictatorship between 1940 and 1945. The socio-economic situation of her family and their proximity to power protected María Aránzazu Vigón from being subject to the dual-model for females that the Franco dictatorship promoted: that of the mother dedicated exclusively to domestic tasks, or "sisters," following the model of Catholic nuns; that is, unmarried women who could develop professional activities under the guardianship of the institutions where they worked. María Aránzazu Vigón did not fit into either of these models. She never married or had children and documentation suggests that the treatment she established with the institutions she worked with was similar to that of her male colleagues. However, she was not totally free from the imposed model of a woman being a mother, as is shown in an interview she did in a section devoted to "important women" in the weekly magazine Blanco y Negro. The picture the journalist chose to illustrate María Aranzazu Vigón as a scientist shows her with her niece, reinforcing this traditional model of the woman in the home (Vázquez-Vigo, 2 Apr. 1960, p.90-91).

She began her studies of science at the University of Oviedo, but had to interrupt them due to the start of the Spanish Civil War. She spent the war years (1936-1939) with her mother and siblings in Buenos Aires (Argentina), and upon her return picked up her studies at the Faculty of Sciences in Madrid, where she graduated in 1942.

As of mid-1940, María Aránzazu Vigón was working on permanent transit between the Naval Laboratory (LTIEMA) and the Optics Institute. José María Otero Navascués used these two institutions to begin enlisting personnel, and to delineate the work lines around which JEN would be structured in the future. Vigón later joined JEN, which was her workplace until her retirement in $1981 .^{1}$ 
María Aránzazu Vigón, Ramón Ortíz Fornaguera, and Carlos Sánchez del Río knew each other well. They had shared work spaces at the Optics Institute under the direction of Otero Navascues, and Ortíz Fornaguera and Sánchez del Río had also shared teaching experiences at the university. Over time, a close personal relationship was also added to the work one. Armando Durán was selected by Otero Navascues as the person responsible for the $214 \mathrm{~kg}$ of uranium, and traveled with it to Rome, representing JIA. Upon arrival there, the uranium was handed over to Edoardo Amaldi, director of the National Institute for Nuclear Physics of the University in Rome, so he could send it to the CISE laboratories in Milan. Amaldi, along with Gilberto Bernardini and Bruno Ferretti, directed the Italian nuclear project that was being developed between the National Institute for Nuclear Physics at the University in Rome and CISE in Milan (Otero Navascués, 11 Jul. 1949, p.2-3).

The three Spanish trainees spent eleven weeks at the Institute of Nuclear Physics in Rome doing various types of work. Their objective was to learn the manufacturing process of radioactivity counters, assemble and disassemble each part into its pieces, understand the function of each one, and be able to analyze the advantages and disadvantages of certain assemblies as compared with others. In the opinion of Otero Navascués, the techniques for manufacturing Geiger-Müller counters needed to be a national project, so the group of physicists had to open and decipher what was inside these unknown black boxes with the aim of learning how to construct them. According to the report that Otero Navascués wrote about this trip, this center manufactured between ten and twelve per day (Otero Navascués, 11 Jul. 1949, p.3). It was María Aránzazu Vigón who focused on studying the techniques used to construct radioactivity counters. After their research stay at the Institute of Nuclear Physics in Rome, María Aránzazu Vigón, Ramón Ortíz Fornaguera, and Carlos Sánchez del Río spent six months at CISE in Milan. At this time CISE was building a low-power heavy water-moderated reactor fueled with natural uranium. Giuseppe Bolla, director of the CISE Technical Commission, incorporated the three Spaniards into the group of 50 engineers and physicists he had under his direction. Ortíz Fornaguera deepened his knowledge of the calculations and theory of reactors, at the time still called piles, and Sánchez del Río and Vigón dedicated their time to studying techniques to construct counters and their circuits, and to measuring radiation with photographic methods.

During her stay in Milan, Vigón verified that the counters they were working with had an even lower performance than those in Rome. Carlos Sánchez del Río, who would later be in charge of the Reactors Division at JEN, also participated in tests that were taking place at CISE to determine the efficient division of uranium fission and measurements for the concentration of heavy water.

In January 1950, Vigón, Sánchez del Río, and Durán (Ortiz Fornaguera had already left for the United States) made another trip to Italy and Switzerland. On the order authorizing the trip, María Aránzazu Vigón is listed as the "chief," in masculine in Spanish, of the JIA physics research service. The head of chemical research at JIA, Antonio Rius Miró, joined the group. They had two assignments: (1) to find out how the reactor project that Vigón and Sánchez del Río, along with Ortíz Fornaguera, had seen one year earlier in Milan had evolved; and (2) to widen their network of contacts in Switzerland. The material and technical possibilities they encountered at the Swiss laboratories seemed suitable for the 
training of Spanish interns. For this reason, they sought out the interlocution of the Director of the Swiss Federal Institute of Technology (Eidgenössische Technische Hochschule, ETH) in Zurich and President of the Swiss Atomic Energy Commission, Paul Scherrer. While enriching technical and research possibilities, the trips also broadened and constructed diplomatic relationships.

\section{Back to Spain}

The experiences, knowledge, and practices that these researchers brought back with them to Spain following their visit to the two Italian research centers were introduced into Spanish research institutions. In the laboratories at the University of Madrid, in those of the Optics Institute, and in the Navy's radio and electronics section, María Aranzazu Vigón's group began to construct portable gamma radioactivity counters, utilizing what they had learned in Italy.

Four publications between 1948 and 1953 in Anales de Física y Química (Spanish Journal of the Society of Physics and Chemistry) describe the tests carried out by the Spanish researchers on the construction of electronic circuits for portable radioactivity detectors. These works refer to the models that inspired them. In addition to what they learned in Italy, the counters built at the University of Lisbon Physics Laboratory (Vigón, Segovia, 1948, p.686), the model for the external-cathode radioactivity counter described by Roland Maze (1946), and the linear accelerator designed by the physicist Matthew Sands at Los Alamos are also mentioned as influences, among others (Elmore, Sands, 1949).

The first tests, focused on preparing radioactivity counters capable of discriminating between alfa, beta, and gamma particles, were done at the electronics laboratories of the University of Madrid in 1948. Although they used some counters that had been built at the University of Lisbon Physics Laboratory, María Aranzazu Vigón's group introduced some modifications. They substituted the counter tube, which in the Portuguese one was made of brass, with a glass one coated with silver. This modification allowed them to test different types of amplifiers useful to record rapid measurements; they tried to eliminate the errors that appeared when the signals they sought to measure were produced in short time intervals (Vigón, Segovia, 1948).

They also designed and built electronic circuits for the counters to detect and study particles and ionizing radiation. These circuits were tested and checked using the GeigerMüller counter tubes that had been built at the Optics Institute laboratories at the Spanish National Research Council (Consejo Superior de Investigaciones Científicas) and at the Faculty of Sciences, University of Madrid, following the research that had been done by María Aránzazu Vigón. These circuits were made up of an electric generator, an amplifier to check the functioning of the counter tubes before being closed, a scaler, and a mechanical enumerator. Additionally, at these laboratories they also worked on a project to construct and test a linear amplifier, following the Model 100 Amplifier that Sands had designed at Los Alamos, USA (Segovia, Verdaguer, Tanarro, 1951).

The next challenge for the Spanish researchers was the construction of a smaller and lighter prototype than those that had been used by the Italians for prospecting. To do this 
they used the Geiger-Müller tubes constructed at the Optics Institute, an electric generator to feed the tube, and a pulse recorder. As the idea was to have a device that was easy to transport, a metal box measuring $20 \times 15 \times 10 \mathrm{~cm}$ was also designed to house the supply batteries. The resulting ensemble was suitable for geological prospection work and searching for radioactive materials, as well as for use in recording rapid measurements in laboratories working with X-rays, radiochemistry, and nuclear physics (Tanarro, Segovia, 1951).

If in the 1940s and 1950s the importance of finding uranium had initially had the objective of constructing increasingly lighter counters that were still dependable, starting from midway through the 1950s this impetus was reinforced by the interest, not only in Western countries, to learn about, evaluate, and monitor the effects of ionizing radiation (Creager, 2013, chapter 10; Herran, 2014). The presence in the archive of the National Radiation Instrument Catalogue of over 150 individual companies, government laboratories, universities, and military organizations that developed portable nuclear radiation instruments shows that this issue was a priority in nuclear programs not only in the United States, but also in Europe and the Soviet Union. This historical archive, begun in the 1940s by the US Atomic Energy Commission, contains entries with over 460 different models from these organizations containing detailed descriptions and over 1,500 images (National..., 2007).

The last initiative I would like to mention is the one using the external cathode GeigerMüller counter designed by Roland Maze (1946). The Spanish researchers saw two basic advantages in this instrument. The first had to do with the position of the cathode. As it was not inside the tube, accumulation of positive charges on the glass wall and continuous discharging was avoided. The second advantage had to do with an even more practical question: ease of construction and the consequent reduction in manufacturing costs. The Spanish researchers adapted the Maze model by modifying and eliminating some of the conditions indicated by Maze in his work. Among them, they simplified the construction of the anode, and used lead glass in place of the sodium glass that Maze had used in his model. Despite the limitations and simplifications used by the Spanish researchers in their tests, the results were satisfactory; some external cathode tubes were constructed and incorporated into the radioactivity counters manufactured in the Spanish laboratories (Celma, García Fité, Segovia, 1953).

Nevertheless, the work with radioactivity counters remained in laboratory trials, along with some prototypes built at the Optics Institute and in the physics and electronics laboratories of the University of Madrid. Certainly, the conversations between the US and Spain that culminated with the signing of the Madrid Agreements in 1953 had something to do with the decision to abandon the initiative to construct the counters in Spanish laboratories and to opt for buying them from the United States, as they were, according to what was said, lighter and easier to use. The radioactivity counters helped expand political and scientific networks with the United States.

Attempts in Spain to reproduce and construct these radioactivity counters show the keen interest of the dictatorship's government, in perfect dialogue with autocratic discourse, to promote national industry. Other attempts were later added to this first one, such as nationalization of the nuclear fuel cycle and everything related to procedures for 
calculating and constructing equipment for the installation of experimental and power nuclear reactors. But the "turnkey" purchase of nuclear reactors, experimental and power, which were installed in Spain as of midway through the 1950s - that is, the purchase of the technology to build a nuclear reactor, which traveled to the country as a complete package - confirms that the efforts to encourage the national industry did not have the desired results (Romero de Pablos, 2012). Despite attempts to construct and replicate certain instruments during the 1950s, the pattern the dictatorship's technocratic government relied on as of the 1960s, and which finally prevailed in Spanish nuclear development, was the purchase, "turnkey," of the technology (Romero de Pablos, Sánchez Ron, 2001, chapter V).

\section{The mediating agency of the radioactivity counters}

As mentioned earlier, the radioactivity counters developed by María Aranzazu Vigón's group participated as mediators in a wide network of political, scientific, and military institutions, Spanish as well as foreign. The $214 \mathrm{~kg}$ of uranium ore extracted from the Spanish mines served initially to pay for trips and the training of interns and to provide three radiation detectors used for mining prospection and exploitation. But they were not the sole instruments mediating this process.

One of the ambitions of the Spanish government after signing the agreement with CISE in 1948 was to develop a nuclear reactor, described in the documentation, as I have already mentioned, by the now obsolete term "atomic pile." The work done by Ramón Ortiz Fornaguera in 1948 with Bruno Ferretti in Rome and in Milan under the direction of Edoardo Amaldi on reactor theory was aimed at reaching this objective. According to Otero Navascués (19 Aug. 1949), the favorable reports that Amaldi and Ferretti sent were decisive to Ortiz Fornaguera being admitted into the Institute for Nuclear Studies at the University of Chicago.

Ramón Ortíz Fornaguera traveled to the United States in September 1949 to work under the direction of Enrico Fermi at the Institute for Nuclear Studies at the University of Chicago, where he remained until November 1950 (Soler Ferrán, 2015). The time he spent in Chicago facilitated the purchase of the radioactivity counter, as is shown by different documents dated between November 1949 and August 1950, preserved in his personal archives. While giving Ortiz Fornaguera the opportunity to travel to the United States to continue his training, this trip contributed to expanding Spanish political and scientific networks. It also opened up new spaces of training and exchange for the Spanish researchers, and facilitated the purchase of books and instruments to equip libraries and laboratories.

During his research stay in Chicago, Ortiz Fornaguera contacted at least three US companies: Precision Radiation Instruments, Radiation Counter Laboratories, and Cyclotron Specialties Company. All of them were then leaders in the construction of radioactivity counters. The Spanish researchers were interested, among others, in Model 101 from Precision Radiation Instruments, and in the Mark 11, Model 10, from Radiation Counter Laboratories (Norman, 29 Mar. 1950, 3 Aug. 1950, 16 Aug. 1950).

Model 101, introduced by Precision Radiation Instruments in 1948, was advertised as "The Finest Portable Count Rate Meter ever developed." It was a new Geiger-Müller 
survey meter with true portability, which could detect beta radiation as low as $160 \mathrm{keV}$, and worked with batteries of $1.5,45$, and 300 volts. The novelty of this new instrument was that it had a Geiger tube with a thin glass wall mounted on a stainless-steel gauge. It was light, weighing just 7.25 pounds - the advertisement claimed that you could lift it with just one finger - and it had a long battery life and allowed for batteries to be replaced without specialized tools. This instrument also had a plug-in probe, making replacement even in the field very simple. The probe was also lightweight and waterproof and had a rugged cable. The Geiger-Müller tube was filled with neon and ethyl ether. In 1948, the company sold this instrument for $\$ 239.50$ per unit (National..., 2007, p.9).

The Mark 11, Model 10, from Radiation Counter Laboratories, was advertised as an alpha, beta, and gamma survey meter. It was introduced in 1950 and was designed for scientists who used radioisotopes that emitted low energy radiation (National..., 2007, p.51).

Various normal bureaucratic problems delayed the receipt of the counters for nearly a year. The difficulty of getting foreign currency, habitual in Spain during those years, was compounded by intermediation problems at the Spanish Embassy in Washington and export formalities. Finally, the Franco government bought three counters from Radiation Counter Laboratories, which were supplied with three spare Geiger tubes and three extra battery sets. Spanish politicians and administrators had put a lot of effort into obtaining what was apparently a small result. Otero Navascués's initial idea of giving priority to nationalizing the technology - constructing their own radioactivity counters - seems to have been pushed into the background when the relationship with the Americans began to flow.

In addition to contacting the main US manufacturers of radioactivity counters and intermediating the purchase of instruments to equip Spanish laboratories, Ortiz Fornaguera's stay in the United States also expanded scientific and political networks. The fluid dialogue he established with Enrico Fermi, former director of the Institute for Nuclear Studies in Chicago, and with its then director, Samuel K. Allison, facilitated the acceptance by the latter of an invitation from Otero Navascués to attend and deliver the closing conference at the Atomic-Nuclear Week held in August 1950 in Santander. Inaugurated by Werner Heisenberg, it featured a good representation of European and North American scientists (Masriera, 23 Aug. 1950, 24 Aug. 1950, 26 Aug. 1950, 27 Aug. 1950; Romero de Pablos, 2018).

Ortiz Fornaguera's stay in the United States was played up somewhat by Otero Navascués to Admiral Luis Carrero Blanco, one of the main authorities in the government and a close confidant of Franco's: “Ortiz [Fornaguera] is the first solid pillar we have placed in America ... He will attract more people. And the basic problem, which is getting a team of personnel trained in good schools and laboratories, starting from where we were one year ago which was at absolute zero, is on a frankly satisfactory path" (Otero Navascués, n.d.; but from the content, it can be deduced it must have been written between Aug. 16 and $20,1949)$. In the rhetoric of Otero Navascués, the scientific and political networks that the radioactivity counters had helped to construct began to bear fruit. 


\section{Final considerations}

People, materials, techniques, and apparatus traveled along with agreements and contracts, changing laboratories, modifying research agendas, and making the institutionalization of nuclear development more dynamic. All this was ultimately used by the nuclear policy authorities to show strengthening political power. While enriching technical and research possibilities, the trips also broadened and constructed diplomatic relationships.

The numbers on the existence of uranium, not only in Spain, that began to circulate at the end of the 1940s and beginning of the 1950s had a lot to do with the development of radioactivity counters and with the efforts by Spanish nuclear policy makers to reproduce and construct them in Spain. The contacts, mediated by uranium, which Spain established with Italy put the United States Atomic Energy Commission (AEC) on alert. The Americans wanted to know about and control the uranium deposits that were beginning to appear in each of the countries. The bilateral agreements that protected technical assistance contracts were the instruments they used to establish these control policies. With Spain, the cooperation agreement was signed in July 1955 (Agreement..., 19 July 1955). Protected by this agreement, technicians and researchers from the Spanish electrical industry and from JEN stopped looking towards Europe and began to travel to the United States; from there, engineers from the AEC came to Spain to control prospecting at the uranium deposits.

The trips allowed those involved to learn about and experiment with instruments, to learn how to equip the laboratories, and also turned them into nuclear researchers. All of them, people, technologies, experiences, materials, began to travel looking for knowledge; these were journeys that, for the Spaniards, weaved new scientific, industrial, and also political alliances, while at the same time strengthened American intelligence programs (Adamson, Camprubí, Turchetti, 2014, p.38).

I suggest that radioactivity counters formed part of a wide network of political, scientific, and military institutions, which played a significant part in Spanish nuclear policy during the Franco dictatorship. Although the knowledge, experiences, and practices that circulated and traveled between Italy and Spain through radioactivity counters did not result in the nationalization of the technology, they did end up being useful for constructing and influencing both nuclear energy and political power during the Franco regime. These instruments were agents in the emergence of these policies.

\section{NOTE}

${ }^{1}$ For a scientific biography of María Aránzazu Vigón, see Romero de Pablos (2017).

\section{REFERENCES}

ADAMSON, Matthew; CAMPRUBÍ, Lino; TURCHETTI, Simone.

From the ground up: uranium surveillance and atomic energy in Western Europe. In: Turchetti,
Simone; Roberts, Peder (ed.). The surveillance imperative: geosciences during the Cold War and beyond. New York: Palgrave MacMillan, p.2344. 2014. 
AGREEMENT...

Agreement for Cooperation between the Government of the United States of America and the Government of Spain concerning civil uses of atomic energy. Archive of the Ministry of Foreign Affairs, Madrid. 19 July 1955.

\section{AGREEMENT BETWEEN...}

Agreement between the Centro di Informazioni, Studii ed Esperienze (CISE) and the Junta de Investigaciones Atómicas (JIA). Archivo Presidencia de Gobierno, Madrid. 1948.

ARNOLD, Ken; SÖDERQVIST, Thomas.

Medical instruments in museums: immediate impressions and historical meanings. Isis, v.102, n.4, p.718-729. 2011.

BENNETT, Jim.

Early modern mathematical instruments. Isis, v.102, n.4, p.697-705. 2011.

BENNETT, Jim.

Presidential address: knowing and doing in the sixteenth century: what were instruments for? British Journal of History of Science, v.36, n.2, p.129-150. 2003.

BOURGUET, Marie-Noëlle; LICOPPE, Christian; SIBUM, H. Otto (ed.).

Instruments, travel and science: itineraries of precision from the seventeenth to the twentieth century. London: Routledge. 2003.

CARBONELL, Antonio.

Nota sobre los minerales de uranio. Ejército, v.72, p.77-78. 1945.

CELMA, Margarita; GARCÍA FITÉ, José; SEGOVIA, Rogelio.

Contadores de cátodo externo. Anales de Física y Química, serie A, p.7-14. 1953.

CHARADEVIAN, Soraya.

Graphical method and discipline: self-recording instruments in nineteenth-century physiology. Studies in History and Philosophy of Science, v.24, n.2, p.267-291. 1993.

CREAGER, Angela N.H.

Life atomic: a history of radioisotopes in science and medicine. Chicago: The University of Chicago Press. 2013.

DASTON, Lorraine.

Things that talk: object lessons from art and science. New York: Zone Books. 2004.

DE LA TORRE, Joseba; RUBIO-VARAS, Maria del Mar.

Nuclear power for a dictatorship: state and business involvement in the Spanish Atomic Program, 1950-85. Journal of Contemporary History, v.51, n.2, p.385-411. 2015a.
DE LA TORRE, Joseba; RUBIO-VARAS, María del Mar.

La financiación exterior del desarrollo industrial español a través del IEME (1950-1982). Estudios de Historia Económica, n.69. Available at: <http:// www.bde.es/bde/es/secciones/informes/

Publicaciones_se/Estudios_de_Hist/>. Access on: 19 Dec. 2017. 2015b.

DISCOVERY...

Discovery of rich uranium deposits in the Spanish Pyrenees. New York Herald Tribune, New York. 27 Sep. 1949.

EDGERTON, David.

Creole technologies and global histories: rethinking how things travel in space and time. History of Science and Technology Journal, v.1, n.1, p.75-112. 2007.

ELMORE, William C.; SANDS, Matthew. Electronic experimental techniques. New York: McGraw-Hill. 1949.

HERRAN, Néstor.

"Unscare" and conceal: the United Nations Scientific Committee on the effects of atomic radiation and the origin of international radiation monitoring. In: Turchetti, Simone; Roberts, Peder (ed.). The surveillance imperative: geosciences during the Cold War and beyond. New York: Palgrave MacMillan. p.69-84. 2014.

HERRAN, Néstor.

Isotope networks: training, sales and publications, 1946-1965, Dynamis, v.29, p.285306. 2009.

HERRAN, Néstor; ROQUÉ, Xavier.

Los físicos en el primer franquismo: conocimiento, poder y memoria. In: Herran, Néstor; Roqué, Xavier (ed.). La física en la dictadura: físicos, cultura y poder en España, 1939-1975. Barcelona: Universitat Autònoma de Barcelona. p.85-104. 2012.

MASRIERA, Miguel.

La Semana Atómico-Nuclear de Santander: las últimas conferencias. La Vanguardia, Barcelona, p.3. 27 Aug. 1950.

MASRIERA, Miguel.

La Semana Atómico-Nuclear de Santander:

Allison habla para La Vanguardia. $\mathrm{La}$

Vanguardia, Barcelona, p.3. 26 Aug. 1950.

MASRIERA, Miguel.

La Semana Atómico-Nuclear de Santander: las conferencias de Heisenberg. La Vanguardia, Barcelona, p.3. 24 Aug. 1950.

MASRIERA, Miguel.

La Semana Atómico-Nuclear de Santander:

Heisenberg habla para La Vanguardia. La Vanguardia, Barcelona, p.3. 23 Aug. 1950. 
MAZE, Roland.

A glass-walled counter with external cathode: compteurs à paroi de verre et à cathode externe. Journal de Physique et le Radium, v.7, n.6, p.164166. 1946.

MENÉNDEZ-NAVARRO, Alfredo.

Átomos para la paz... y para la medicina: la popularización de las aplicaciones médicas de la energía nuclear en España. Revista Española de Medicina Nuclear, v.26, n.6, p.385-399. 2007.

MENÉNDEZ-NAVARRO, Alfredo; SÁNCHEZ VÁZQUEZ, Luis.

Radiological protection in the Spanish nuclear industry under Franco, 1939-1975. História, Ciências, Saúde - Manguinhos, v.20, n.3, p.797812. 2013.

\section{NATIONAL...}

National Radiation Instrument Catalogue, 1920-1960. Available at: <http://www.nationalradiation-instrument-catalog.com/>. Access on: 13 Dec. 2007.

NIETO-GALÁN, Agustí.

From papers to newspapers: Miguel

Masriera (1901-1981) and the role of science popularization under the Franco regime. Science in Context, v.26, n.3, p.527-549. 2013.

NIETO-GALÁN, Agustí.

Miguel Masriera (1901-1981) y la divulgación de la física nuclear en la España de Franco. In: Herran, Nestor; Roqué, Xavier (ed.). La física en la dictadura: físicos, cultura y poder en España, 1939-1975. Barcelona: Universitat Autònoma de Barcelona, p. 277-294. 2012.

NORMAN, L.

Letter to Ramón Ortiz Fornaguera. Archive Ortiz Fornaguera, Universitat Autònoma de Barcelona. Available at: <http://ddd.uab.cat/ record/140848?ln=es>. Access on: 4 Dec. 2017. 16 Aug. 1950.

NORMAN, L.

Letter to Ramón Ortiz Fornaguera. Archive Ortiz Fornaguera, Universitat Autònoma de Barcelona. Available at: <http://ddd.uab.cat/ record/140848? ln=es $>$. Access on: 4 Dec. 2017. 3 Aug. 1950.

NORMAN, L.

Letter to Ramón Ortiz Fornaguera. Archive Ortiz Fornaguera, Universitat Autònoma de Barcelona. Available at: <http://ddd.uab.cat/ record/140848?ln=es>. Access on: 4 Dec. 2017. 29 Mar. 1950.

ORDÓÑEZ, Javier; RAMÍREZ, Felipe E. Los públicos de la ciencia española: un estudio del No-Do. In: Romero de Pablos, Ana; Santesmases, María Jesús (ed.). Cien años de política científica en España. Madrid: Fundación BBVA. p.257-292. 2008.

ORDÓÑEZ, Javier; SÁNCHEZ RON, José Manuel. Nuclear energy in Spain: from Hiroshima to the sixties. In: Forman, Paul; Sánchez Ron, José Manuel (ed.). National military establishments and the advancement of science and technology: studies in 20th century history. Dordrecht: Kluwer. p.185-213. 1996.

OTERO NAVASCUÉS, José María.

Letter to Luis Carrero Blanco, Subsecretary of the Presidency of the Government. Archive Presidency of the Government. n.d.

OTERO NAVASCUÉS, José María.

Letter to Ramon Ortiz Fornaguera. Archive Ortiz Fornaguera (Universitat Autònoma de Barcelona, Barcelona). Available at: <http://ddd.uab.cat/ collection/rof?ln=es >. Access on: 4 Dec. 2017. 19 Aug. 1949.

OTERO NAVASCUÉS, José María.

Memoria de la Junta de Investigaciones Atómicas que eleva a la superioridad su Presidente, D. José María Otero Navascués, Teniente coronel de armas navales, miembro de número de la Real Academia de Ciencias Exactas, Físicas y Naturales. Archivo Presidencia de Gobierno, Madrid. 11 Jul. 1949.

PANCALDI, Giuliano. Appropriating invention: the reception of the voltaic battery in Europe. In: Bourguet, MarieNoëlle; Licoppe, Christian; Sibum, H. Otto (ed.). Instruments, travel and science: itineraries of precision from the seventeenth to the twentieth century. London: Routledge. p.126-155. 2003.

PRESAS, Albert.

Políticas para la ciencia en la España de Franco. In: Romero de Pablos, Ana; Santesmases, María Jesús (ed.). Cien años de política científica en España. Madrid: Fundación BBVA. p.173-210. 2008.

RAMÍREZ MARTÍNEZ, Felipe, E.

Ciencia, tecnología y propaganda en el noticiario oficial del franquismo No-Do (1943-1964). Thesis (PhD) - Universidad Autónoma de Madrid, Madrid. Available at: <https://consigna.ugr.es/g/ fscvkr0GyENZABWo/Tesis\%20doctoral\%20 Ramirez_Martinez_Felipe_E\%202011.pdf>. Access on: 10 Dec. 2017. 2011.

RENTETZI, Maria.

Trafficking materials and gendered experimental practices: radium research in early 20 th century Vienna. New York: Columbia University Press. 2008.

RENTETZI, Maria.

Gender, politics, and radioactivity research in interwar Vienna: the case of the Institute for Radium Research. Isis, v.9, n.3, p.359-393. 2004. 
RHEINBERGER, Hans-Jörg.

Putting isotopes to work: liquid scintillation counters, 1950-1970. In: Joerges, Bernward; Shinn, Terry. Instrumentation: between science, state and industry. Dordrecht: Kluwer Academic Publisher. 2001.

RHEINBERGER, Hans-Jörg. Toward a history of epistemic things. Stanford: Stanford University Press. 1997.

ROMERO DE PABLOS, Ana.

Prensa y tecnología en la España de Franco: del secreto a la política atómica pública. Dynamis, v.38, n.1, p.189-218. 2018.

ROMERO DE PABLOS, Ana.

Mujeres científicas en la dictadura de Franco: trayectorias investigadoras de Piedad de la Cierva y María Aránzazu Vigón. Arenal. Revista de Historia de las Mujeres, v.24, n.2, p.319-348. 2017.

ROMERO DE PABLOS, Ana.

Energía nuclear e industria en la España de mediados del siglo XX. Zorita, Garoña y Vandellòs 1. Herran, Nestor; Roqué, Xavier. La física en la dictadura: físicos, cultura y poder en España, 1939-1975. Barcelona: Universidad Autònoma de Barcelona, p.45-64. 2012.

ROMERO DE PABLOS, Ana; SÁNCHEZ RON, José Manuel.

Energía nuclear en España: de la JEN al CIEMAT. Madrid: CIEMAT/Doce Calles. 2001.

SANTESMASES, María Jesús.

The circulation of penicillin in Spain: health, wealth and authority. London: Palgrave. 2018.

SANTESMASES, María Jesús.

From prophylaxis to atomic cocktail: circulation of radioiodine. Dynamis, v.29, p.337-364. 2009.

SANTESMASES, María Jesús.

Peace propaganda and biomedical experimentation: radioisotopes in endocrinology and molecular genetics, and their influence in Spain (1950-1971). Journal of the History of Biology, v.39, n.4, p.765-798. 2006.

SECORD, James A.

Knowledge in transit. Isis, v.95, n.4, p.654-672. 2004.

SEGOVIA, Rogelio; VERDAGUER, Francisco; TANARRO, Agustín.

Equipo electrónico para detección y studio de partículas y radiaciones ionizantes. Anales de Física y Química, serie A, p.29-34. 1951.

SCHAFFER, Simon.

Easily cracked: scientific instruments in states of disrepair. Isis, v.102, n.4, p.706-717. 2011.
SCHAFFER, Simon.

L'inventaire de l'astronome: le commerce d'instruments scientifiques au XVIIIe siècle. Annales: Histoire, Sciences Sociales, v.4, 60e année, p.791-815. 2005.

SOLER FERRÁN, Pablo.

La obra científica de Ramón Ortiz Fornaguera (1916-1974): un capítulo de la física matemática, teórica y nuclear en la dictadura franquista. Actes d'història de la ciència i de la técnica, v.8, p.9-55. 2015.

SUÁREZ-DÍAZ, Edna; MATEOS, Gisela;

BARAHONA, Ana.

Across borders: science and technology during the Cold War: an introduction. Dynamis, v.35, n.2, p.271-278. 2015.

TANARRO, Agustín; SEGOVIA, Rogelio.

Detector y medidor portátil de radiactividad, Anales de Física y Química, serie A, p.193-196. 1951.

TAUB, Liba.

Introduction. Reengaging with instruments. Isis, v.102, n.4, p.689-696. 2011.

TURCHETTI, Simone; HERRAN, Néstor; BOUDIA, Soraya.

Introduction: have we ever been

"transnational"? Towards a history of science across and beyond borders. British Journal for the History of Science, v. 45, n.3, p.319-336. 2012.

URANIO.

Uranio: cursos de conferencias. Madrid:

Memorias del Instituto Geológico y Minero de España. 1946.

VALVERDE, Nuria.

Meanings of waves: electroencephalography and society in Mexico City, 1940-1950. Science in Context, v.29, n.4, p.451-472. 2016.

VAN HELDEN, Albert; HANKINS Thomas L. (Ed.). Instruments. Osiris, v.9, p.1-7. 1994.

VÁZQUEZ-VIGO, Carmen.

María Aránzazu Vigón: miembro de la Junta de Energía Nuclear. Blanco y Negro, Madrid, p.90-91. 2 Apr. 1960.

VIGÓN, María Aránzazu; SEGOVIA, Rogelio. Sobre la construcción de contadores de Geiger y circuitos electrónicos asociados. Anales de la Real Sociedad Española de Física y Química, v.44, serie A, p.686-689. 1948.

WARNER, Deborah Jean.

What is a scientific instrument, when did it become one, and why? The British Journal for the History of Science, v.23, n.1, p.83-93. 1990. 